\begin{tabular}{|ccc|}
\hline JURNALASI & Jurnal Inovasi Teknologi Pendidikan & T P | \\
INOVIASI & Volume 3, No 1, April 2016 (40-52) & T \\
PENDIDIKAN & Online: http://journal.uny.ac.id/index.php/jitp & $\begin{array}{l}\text { lkatan Profesi Teknologi } \\
\text { Pendidikan Indonesia }\end{array}$ \\
\hline \hline
\end{tabular}

\title{
KEEFEKTIFAN METODE INQUIRY TERHADAP KEAKTIFAN DAN HASIL BELAJAR SISWA KELAS X PEMBELAJARAN KIMIA
}

\author{
Nurdiansah Dwi Sasongko, Haryanto \\ Universitas Ma'arif Nahdlatul Ulama Kebumen, Universitas Negeri Yogyakarta \\ sahabatsasongko@gmail.com, haryanto_tp@uny.ac.id
}

\begin{abstract}
Abstrak
Penelitian ini bertujuan untuk mengetahui adanya perbedaan keefektifan penggunaan metode inquiry dan metode demonstrasi dalam pembelajaran kimia pokok bahasan hidrokarbon terhadap keaktifan belajar peserta didik dan hasil belajar peserta didik MA AlFalah Jatilawang. Jenis penelitian ini adalah quasi experiment dengan desain adalah pretestposttest control group design. Populasi penelitian ini adalah seluruh peserta didik kelas X MA Al-Falah Jatilawang pada semester kedua tahun ajaran 2013/2014. Sampel dipilih dua kelas yaitu kelas X1 dan X2 dengan menggunakan teknik simple random sampling. Hasil penelitian ini menunjukan bahwa terdapat perbedaan yang signifikan antara metode pembelajaran inquiry dan metode pembelajaran demonstrasi dalam pembelajaran kimia pokok bahasan hidrokarbon terhadap keaktifan belajar peserta didik dan hasil belajar peserta didik MA AlFalah Jatilawang. Metode pembelajaran inquiry lebih efektif dari pada metode pembelajaran demonstrasi dalam pembelajaran kimia pokok bahasan hidrokarbon terhadap keaktifan dan hasil belajar peserta didik MA Al-Falah Jatilawang.
\end{abstract}

Kata kunci : Metode Inquiry, Metode Demonstrasi, Keaktifan Belajar, Hasil Belajar

\section{THE EFFECTIVENESS OF THE INQUIRY METHOD IN THE LEARNING ACTIVENESS AND OUTCOMES OF GRADE X STUDENTS IN CHEMISTRY LEARNING}

\author{
Nurdiansah Dwi Sasongko, Haryanto \\ Universitas Ma'arif Nahdlatul Ulama Kebumen, Universitas Negeri Yogyakarta \\ sahabatsasongko@gmail.com, haryanto_tp@uny.ac.id
}

\section{Abstract}

This study aims to investigate the difference in the effectiveness of the use of the inquiry method and the demonstration method in chemistry learning for the topic of hydrocarbon in terms of the learning activeness and outcomes of the students of MA Al-Falah Jatilawang. This was a quasiexperimental study employing pretest-posttest control group design. The research population comprised Grade X students of MA Al-Falah Jatilawang in the second semester of the academic year of 2013/2014. The sample, consisting of Grades X1 and X2, was selected by means of the simple random sampling. The results of the study showed that there was a significant difference between the inquiry learning method and the demonstration learning method in chemistry learning for the topic of hydrocarbon in terms of the learning activeness and outcomes of the students of MA Al-Falah Jatilawang. The inquiry learning method was more effective than the demonstration learning method in chemistry learning for the topic of hydrocarbon in terms of the learning activeness and outcomes.

Keywords: inquiry method, demonstration method, learning activeness, learning outcomes 



\section{Pendahuluan}

Berdasarkan observasi awal yang dilakukan peneliti, Selasa 22 Oktober 2013 di MA Al-Falah dalam pembelajaran kimia kurang sesuai dengan yang diharapkan, apabila dikaitkan dengan proses dan hasil belajar peserta didik terhadap materi pelajaran kimia. Berdasarkan proses pembelajaran, pendidik masih terlalu mendominasi proses pembelajaran sehingga peserta didik cenderung pasif dalam menerima pelajaran. Dilihat dari hasil pembelajaran, masih banyak peserta didik yang hasil belajarnya dibawah KKM (nilai kurang dari $75,00)$.

Terlihat saat observasi awal tersebut dalam proses pembelajaran pendidik menggunakan metode pembelajaran demonstrasi. Demonstrasi yang dimaksud adalah pendidik menunjukan perilaku dan sifat-sifat sesuatu, mencoba sesuatu dihadapan peserta didik tanpa ada keharusan bagi peserta didik untuk mencobanya sendiri (Suyono dan Hariyanto, 2012, p. 220). Pendidik melakukan demonstrasi dengan menunjukan bagaimana pembentukan ikatan kovalen dengan menggunakan molimod.

Penggunaan metode pembelajaran demonstrasi di depan kelas oleh pendidik membuat peserta didik hanya melihat dan mencatat apa yang diajarkan pendidik. Hal lain yang terlihat adalah sedikit sekali peserta didik yang bertanya tentang materi pelajaran yang diajarkan walaupun pendidik memberikan kesempatan peserta didik untuk bertanya serta apabila pendidik menyuruh peserta didik untuk menjawab pertanyaan atau mendemonstasikan di depan kelas hampir semua peserta didik tidak berani maju ke depan kelas. Ketidakaktifan peserta didik didalam kelas berbanding lurus dengan hasil belajar peserta didik. Hal ini tampak dari tabel rerata hasil belajar peserta didik pada nilai ulangan harian kimia di kelas X MA Al-Falah tahun ajaran 2013/2014 disajikan pada Tabel 1 sebagai berikut.
Tabel 1. Nilai Rata-Rata Ulangan Harian Kimia Kelas X

\begin{tabular}{cc}
\hline Kelas & $\begin{array}{c}\text { Nilai Rata-Rata } \\
\text { Ulangan Harian }\end{array}$ \\
\hline X.1 & 61,35 \\
X.2 & 66,20 \\
X.3 & 64,40 \\
\hline
\end{tabular}

Proses pembelajaran tersebut bertolak belakang dengan karakteristik pembelajaran kimia. Mulyasa (2008, p. 133) menyatakan bahwa pembelajaran kimia menekankan pada pemberian pengalaman belajar secara langsung melalui penggunaan dan pengembangan keterampilan proses dan sikap ilmiah. Pendidik bukan sebagai satu-satunya sumber belajar, akan tetapi pendidik berperan sebagai perencana pembelajaran, pengelola pembelajaran, fasilitator dan sebagai evaluator dalam mengontrol kegiatan yang dilaksanakan oleh peserta didik. Keberhasilan proses pembelajaran tidak diukur dari sejauh mana materi pelajaran yang telah disampaikan pendidik akan tetapi sejauh mana peserta didik telah aktif mencari dan menemukan materi pelajaran sendiri (process oriented).

Salah satu solusi untuk mengatasi permasalahan di atas adalah pendidik memilih dan menerapkan metode pembelajaran selain demonstrasi yang sesuai dan didasari pengertian mendalam dari pendidik akan keaktifan dan hasil belajar peserta didik. Keaktifan adalah kegiatan yang bersifat fisik maupun mental, yaitu berbuat dan berfikir sebagai suatu rangkaian yang tidak dapat dipisahkan (Sardiman, 2014, p. 100) dan hasil belajar merupakan hasil dari suatu interaksi tindak belajar dan tindak mengajar, dari sisi pendidik, tindak mengajar diakhiri dengan proses evaluasi hasil belajar sedangkan dari sisi peserta didik, hasil belajar merupakan berakhirnya pengajaran dari puncak proses belajar (Dimyati dan Mudjiono, 2009, p. 3). Salah satu metode pembelajaran yang dimungkinkan dapat meningkatkan keaktifan dan hasil belajar peserta didik adalah metode pembelajaran inquiry. 
Jeffrey dan Adam (2009, p. 122) menyatakan inquiry-based teaching, or guided discovery, has been shown to stimulate learn. In their quest for knowledge and understanding by helping them form and answer their own question about their word. Fundamental to inquiry is identifying, asking and discussion questions, especially one pertinent to the student or the community, and considering methods to discover, evaluate, and apply answer to the question. Learner-centered inquiry also provides explanation of relevant information and formative assessments (feedback mechanisms and monitoring) and continuous adaptation that lead to potential solutions to students question. Inquiry is increasingly and enduringly mediated by literacy which technological applications.

Maksudnya bahwa pembelajaran inquiry, atau penemuan terbimbing, bertujuan untuk merangsang peserta didik belajar. dalam upaya peserta didik mencari pengetahuan dan pemahaman dengan membantu mereka membentuk dan menjawab pertanyaan mereka sendiri. Hal yang paling mendasar untuk mencari pengetahuan dan pemahaman adalah mengidentifikasi, mengajukan pertanyaan dan diskusi, terutama yang berkaitan dengan peserta didik atau masyarakat belajar, dan mempertimbangkan metode untuk menemukan, mengevaluasi, dan menerapkan jawaban atas pertanyaan.

Gulo (Trianto, 2012, p. 166) menyatakan bahwa metode pembelajaran inquiry adalah suatu rangkaian kegiatan belajar yang melibatkan secara maksimal seluruh kemampuan peserta didik untuk mencari dan menyelidiki secara sistematis, kritis, logis, analisis, sehingga mereka dapat merumuskan sendiri penemuannya dengan penuh percaya diri. Sasaran utama kegiatan pembelajaran dengan metode pembelajaran inquiry adalah keterlibatan peserta didik secara maksimal dalam proses pembelajaran, keterarahan kegiatan yang logis dan sistematis pada tujuan pembelajaran dan mengembangkan sikap percaya diri peserta didik tentang apa yang ditemukan dalam pelaksanaan metode pembelajarn inquiry.

Tentunya tidak semua materi kimia harus diajarkan dengan melalui metode pembelajaran inquiry, karena peserta didik dituntut untuk belajar aktif untuk mempelajari, meneliti dan berdiskusi tentang materi pelajaran yang diajarkan, untuk itu harus dipilih materi yang kompetensi dasarnya memungkinkan peserta didik untuk melakukan hal yang telah disebutkan di atas. Pemilihan materi ini sebagai upaya menghidari materi-materi yang tidak tepat untuk digunakan dengan metode pembelajaran inquiry sehingga tujuan pembelajaran dapat tercapai. Materi yang dipilih dalam penelitian ini adalah materi hidrokarbon kelas $X$ semester 2 yang memiliki kompetensi dasar mendeskripsikan struktur, cara penulisan, tata nama, sifat, kegunaan dan identifikasi senyawa karbon.

Metode pembelajaran inquiry dimungkinkan cocok untuk diterapkan dalam pembelajaran kimia pokok bahasan hidrokarbon yang banyak bersifat hafalan, materi yang padat dan abstrak. Hal ini karena metode inquiry lebih menekankan pada proses berfikir secara kritis dan analisis, serta banyak melibatkan aktivitas peserta didik seperti mempelajari, meneliti, berdiskusi dan menyampaikan informasi. Hal ini akan lebih membuat proses pembelajaran menjadi lebih menarik dan berkesan, karena peserta didik terlibat langsung dalam proses pembelajaran. Semakin aktif peserta didik, diharapkan akan berbanding lurus dengan hasil belajar peserta didik pada proses pembelajaran kimia pokok bahasan.

Berdasarkan latar belakang, maka rumusan masalah dalam penelitian ini adalah (1) adakah perbedaan yang signifikan penerapan metode pembelajaran inquiry dibandingkan dengan metode pembelajaran demonstrasi terhadap keaktifan belajar peserta didik? (2) adakah perbedaan yang signifikan penerapan metode pembelajaran inquiry dibandingkan dengan metode pembelajaran demonstrasi terhadap hasil belajar peserta didik? sedangkan tujuan dari 
penelitian ini adalah untuk mengetahui, (1) ada tidaknya perbedaan yang signifikan penerapan metode pembelajaran inquiry dibandingkan dengan metode demonstrasi terhadap keaktifan belajar peserta didik. (2) Ada tidaknya perbedaan yang signifikan penerapan metode pembelajaran inquiry dibandingkan dengan metode pembelajaran demonstrasi terhadap hasil belajar peserta didik.

\section{Metode Penelitian}

Jenis penelitian yang digunakan dalam penelitian ini adalah jenis penelitian eksperimen semu atau quasi eksperimen, jadi penelitian harus dilakukan secara kondisional dengan tetap memperhatikan faktor-faktor yang mempengaruhi validitas hasil penelitian. Desain quasi eksperimen pada penelitian ini adalah pretest-posttest control group design.

Populasi penelitian ini adalah peserta didik kelas $X$ semester $2 \mathrm{MA}$ AlFalah Jatilawang Banyumas tahun ajaran 2013-2014. Jumlah populasi keseluruhan 60 peserta didik yang terbagi dalam 3 kelas.

Teknik pengambilan sampel yang digunakan dalam penelitian ini adalah teknik simple random sampling. Pengambilan sampel dalam penelitian ini menggunakan undian yang dilakukan dalam satu tahap dengan dua kali pengambilan. Dari 3 kelas X MA Al-Falah, diperoleh sampel kelas X1 diberi pembelajaran dengan menggunakan metode pembelajaran demonstrasi dan X2 diberi pembelajaran dengan menggunakan metode pembelajaran inquiry. Sebelum diberi perlakuan, masing-masing sampel diuji kesetaraannya terlebih dahulu yaitu dengan menguji kesamaan rata-rata dari nilai ujian semester gasal. Dari perhitungan Uji $\mathrm{t}$ independent sample test diperoleh nilai $\operatorname{sig}=0,478(\operatorname{sig}>0,05)$. Hal ini dapat diartikan bahwa Ho diterima (tidak terdapat perbedaan kemampuan belajar antara kedua sampel yang akan digunakan sebagai kelas eksperimen).

Pengumpulan data menggunakan teknik non tes dan teknis tes, teknis non tes terdiri dari observasi dan angket sedangkan teknik tes terdiri dari pretest dan posttest. Observasi dilakukan untuk mengetahui keaktifan peserta didik. Observasi yang dilakukan dalam penelitian ini adalah observasi dengan menggunakan instrumen lembar observasi yang sudah diketahui variabel yang diamati. Observasi dilakukan oleh pendidik kimia kelas $X$ dengan cara mengamati keaktifan yang dilakukan peserta didik selama proses pembelajaran sesuai dengan variabel keaktifan yang terdapat di dalam lembar observasi. Angket digunakan untuk mengetahui respons peserta didik tentang keaktifan mereka dalam mengikuti proses pembelajaran. Angket diberikan kepada peserta didik setelah peserta didik diberi perlakuan yaitu kelas kontrol menggunakan metode pembelajaran demonstrasi dan kelas eksperimen dengan menggunakan metode pembelajaran inquiry. Pretest dimaksudkan untuk mengukur kemampuan awal peserta didik sebelum diberi perlakuan. Pretest menggunakan soal-soal pilihan ganda berjumlah 25 soal. Posttest dimaksudkan untuk mengetahui seberapa jauh kompetensi dasar atau indikator yang disampaikan saat perlakuan telah dikuasai peserta didik. Posttest menggunakan soal-soal pilihan ganda berjumlah 25 soal.

Analisis data yang dilakukan adalah menganalisis dua data yang berbeda yaitu data yang diperoleh dari instrumen nontes dan data yang diperoleh dari instrumen tes. Data yang dihasilkan akan dianalisis untuk membutikan hipotesis penelitian.

Analisis data dilakukan dengan 3 analisis yaitu (1) analisis data hasil observasi (2) analisis data angket keaktifan (3) analisis data tes hasil belajar.

Analisis data dari observasi kegiatan peserta didik dalam penelitian ini adalah merefleksikan hasil pengamatan berupa keaktifan belajar peserta didik dianalisis dengan langkah-langkah yaitu (1) berdasarkan pedoman penskoran yang telah dibuat, dihitung jumlah skor tiap-tiap hasil pengamatan yaitu "ya" dan "tidak" untuk 
masing-masing peserta didik (2) Hasil penjumlahan semua skor "ya" dan "tidak" kemudian dipresentasekan untuk membuat kesimpulan mengenai keaktifan belajar peserta didik di kelas.

Adapun rumus data presentase keaktifan belajar peserta didik adalah sebagai berikut.

Dimana:

$$
P=\frac{f}{N} x 100 \%
$$

$\mathrm{P}$ : angka presentase

$f$ : frekuensi yang sedang dicari presentasenya

$\mathrm{N}$ : Number of case (jumlah frekuensi/banyaknya individu)

(Anas Sudjono, 2013, p. 43)

Adapun hasil data observasi dianalisis dengan pedoman Kriteria pada tabel berikut (Sugiyono, 2012, p. 99).

Tabel 2. Kriteria Keaktifan Peserta Didik

\begin{tabular}{cc}
\hline Presentase & Kriteria \\
\hline $75 \%-100 \%$ & Sangat Tinggi \\
$50 \%-74,99 \%$ & Tinggi \\
$25 \%-49,99 \%$ & Sedang \\
$0 \%-24,99 \%$ & Rendah \\
\hline
\end{tabular}

Analisis data dari hasil angket yang telah disebarkan kepada responden dihitung dan ditabulasikan lalu dipresentasikan dari seluruh jawaban kuantitatif yang disediakan. Sugiyono menyatakan bahwa (2010, p. 137) data diinterpretasikan dengan cara sebagai berikut. Pertama, menghitung jumlah skor kriterium. Skor kriterium merupakan skor jika setiap butir mendapat skor tertinggi.

Rumus

Skor tertinggi $\mathrm{x}$ jumlah butir soal $\mathrm{x}$ Jumlah responden

Kedua adalah menghitung jumlah skor hasil pengumpulan data, skor-skor yang diperoleh dari responden, ditabulasikan dalam tabel dan dihitung jumlah keseluruhan skor data kuantitatif yang dipilih seluruh responden. Ketiga, menentukan kategori atau interpretasi data. Setelah diketahui jumlah skor kriterium dan jumlah skor hasil pengumpulan data, dihitung skor kualitas dengan cara berbagai berikut.

Jumlah skor hasil pengumpulan data Jumlah Skor kriterium

X $100 \%$

Analisis data tes hasil belajar dilakukan dengan cara uji hipotesis dengan uji t, maka sebelum dilakukan analisis data terlebih dahulu harus dilakukan uji persyaratan hipotesis yang terdiri dari uji homogenitas dan uji normalitas. Semua hasil analisis data tes hasil belajar diolah menggunakan SPSS 16.

\section{Hasil Penelitian dan Pembahasan}

Penelitian ini menggunakan tiga data, yaitu data sebelum perlakuan, data saat perlakuan dan data setelah perlakuan yang dilakukan pada kelas kontrol dan kelas eksperimen. Data sebelum perlakuan memuat data pretest hasil belajar kimia peserta didik pada pokok bahasan hidrokarbon dengan tujuan untuk mengetahui pengetahuan peserta didik sebelum diberikan perlakuan. Data saat perlakuan memuat data observasi yang dilakukan oleh pendidik kimia kelas $\mathrm{X}$ selama proses pembelajaran berlangsung dengan tujuan untuk mengetahui keaktifan belajar peserta didik, sedangkan data setelah perlakuan memuat data tentang posttest hasil belajar peserta didik dengan tujuan untuk mengetahui hasil belajar peserta didik setelah mendapatkan perlakuan dan data angket tentang keaktifan peserta didik dengan tujuan untuk mengetahui respos peserta didik tentang keaktifan mereka selama proses pembelajaran berlangsung.

Data Keaktifan Belajar Peserta Didik Kelas Kontrol dan Kelas Eksperimen

Data keaktifan belajar kimia peserta didik diperoleh dari dua data, yaitu yang pertama, data observasi yang dilakukan selama proses pembelajaran, dimana kelas kontrol diberi perlakuan menggunakan metode pembelajaran demonstrasi dan 
kelas eksperimen menggunakan metode pembelajaran inquiry. Kedua, diperoleh dari data angket yang diberikan kepada peserta didik setelah mengikuti proses pembelajaran dimana kelas kontrol menggunakan metode pembelajaran demonstrasi dan kelas eksperimen menggunakan metode pembelajaran inquiry.

Data Hasil Observasi Keaktifan Belajar Peserta Didik

Observasi dilaksanakan selama proses pembelajaran berlangsung. Hal yang diamati berupa keaktifan peserta didik yang muncul selama proses pembelajaran berlangsung. Data tersebut disajikan dalam bentuk histogram pada Gambar 1.

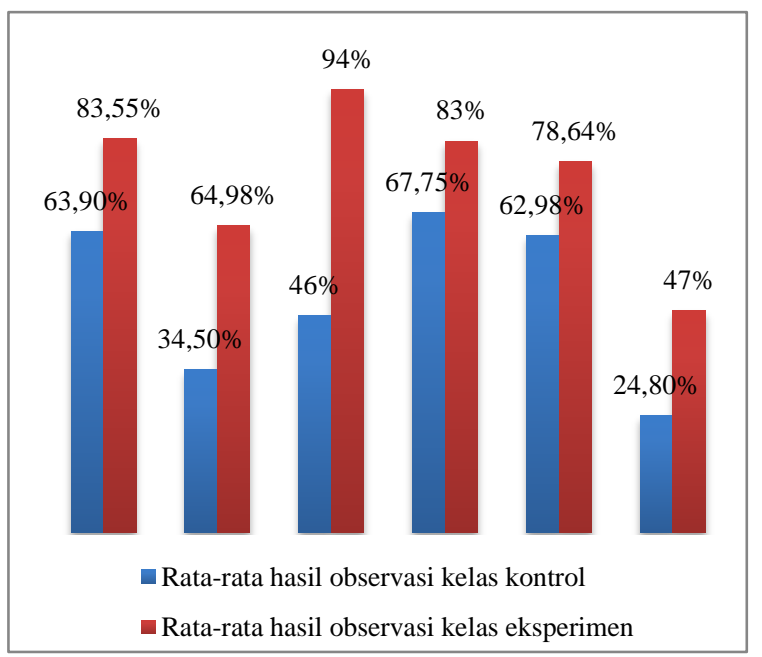

Gambar 1. Rata-Rata Hasil Observasi Keaktifan Belajar Kimia Kelas Kontrol Dan Kelas Eksperimen

Terlihat pada histogram di atas bahwa presentase kelas kontrol untuk jenis mental activities masih tergolong rendah, sedangkan oral activities dan listening activities masih tergolong sedang, dan untuk motor activities, visual activities, writing activities sudah tergolong tinggi. Terlihat pula bahwa presentase kelas eksperimen untuk jenis mental acitivities masih tergolong sedang dan oral activities sudah tergolong tinggi, sedangkan motor activities, writing activities, visual activities dan listening activities sudah tergolong sangat tinggi. Se- cara keseluruhan presentase data observasi keaktifan belajar kimia peserta didik kelas eksperimen mempunyai hasil observasi yang lebih besar dibandingkan dengan kelas kontrol.

\section{Data Hasil Angket Keaktifan Belajar Peserta Didik}

Berdasarkan angket yang disebarkan kepada peserta didik di akhir pembelajaran, diperoleh data mengenai keaktifan peserta didik berdasarkan pada apa yang peserta didik lakukan selama proses pembelajaran berlangsung. Data disajikan dalam bentuk histogram pada Gambar 2.

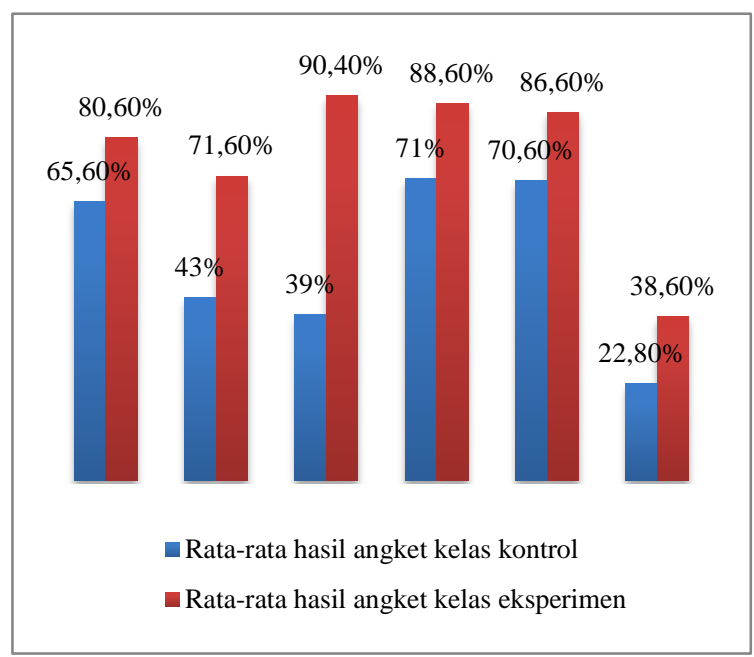

Gambar 2. Rata-rata hasil angket keaktifan belajar kimia kelas kontrol dan kelas eksperimen

Terlihat pada histogram di atas bahwa presentase kelas kontrol untuk jenis mental activities masih tergolong rendah, sedangkan oral activities dan listening activities masih tergolong sedang, dan untuk motor activities, visual activities, writing activities sudah tergolong tinggi. Terlihat pula bahwa presentase kelas eksperimen untuk jenis mental acitivities masih tergolong sedang dan oral activities sudah tergolong tinggi, sedangkan motor activities, writing activities, visual activities dan listening activities sudah tergolong sangat tinggi. Secara keseluruhan presentase data angket keaktifan belajar kimia peserta didik kelas eksperimen mempunyai hasil angket yang 
lebih besar dibandingkan dengan kelas kontrol.

\section{Uji Hipotesis Keaktifan Peserta Didik}

Berdasarkan data hasil observasi dan angket, diperoleh data keaktifan peserta didik kelas eksperimen $>$ kelas kontrol. Artinya ada perbedaan keaktifan belajar peserta didik yang mengikuti proses pembelajaran dengan menggunakan metode pembelajaran inquiry dengan pesera didik yang mengikuti proses pembelajaran dengan menggunakan metode pembelajaran demonsrasi. Peserta didik yang mengikuti proses pembelajaran dengan mengikuti metode pembelajaran inquiry lebih aktif dari pada peserta didik yang mengikuti proses pembelajaran dengan metode pembelajaran demonstrasi.

Data Hasil Belajar Peserta Didik Kelas Kontrol dan Kelas Eksperimen

Data yang digunakan dalam penelitian ini diambil dari hasil tes. Tes yang diberikan berupa pretest dan posttest. Pretest diberikan sebelum melakukan proses belajar mengajar pada pokok bahasan hidrokarbon. Sedangkan posttest diberikan setelah menerapkan pembelajaran kimia dengan menggunakan metode pembelajaran demonstrasi pada kelas kontrol dan metode pembelajaran inquiry pada kelas eksperimen. Data skor pretest dan skor posttest diperoleh dari 40 peserta didik yang terdiri dari 20 peserta didik pada kelas kontrol dan 20 peserta didik pada kelas eksperimen. Hasil belajar peserta didik berupa aspek kognitif dengan menggunakan instrumen tes berupa tes soal objektif pilihan ganda sebanyak 25 soal.

Uji Normalitas Pretest Kelas Kontrol dan Kelas Eksperimen

Sebelum dilakukan pengolahan data lebih lanjut dilakukan pengujian prasyarat penelitian yaitu uji normalitas. Pengujian normalitas dalam penelitian ini menggunakan uji Kolmogorov-Smirnov dimana Pengambilan keputusan didasar- kan dengan ketentuan pengujian hipotesis normalitas dengan melihat nilai Sig. dan menggunakan taraf signifikansi $(\alpha=5 \%)$, yaitu apabila nilai Sig. $>$ a, maka data berdistribusi normal, dan sebaliknya jika nilai Sig. $<$ a maka data tidak berdistribusi normal. Uji normalitas pada penelitian ini dapat dilihat pada tabel berikut.

Tabel 3. Hasil Uji Normalitas Pretest Kelas Kontrol dan Kelas Eksperimen

\begin{tabular}{llrr}
\hline & & $\begin{array}{c}\text { kelas } \\
\text { kontro } \\
1 \\
\text { pretest }\end{array}$ & $\begin{array}{c}\text { kelas } \\
\text { eksperim } \\
\text { en pretest }\end{array}$ \\
\hline $\mathrm{N}$ & 20 & 20 \\
$\begin{array}{l}\text { Normal } \\
\text { Parameters } \\
(\mathrm{a}, \mathrm{b})\end{array}$ & Mean & 47.00 & 46.40 \\
& Std. & & \\
& Deviation & 9.526 & 5.093 \\
Most & Absolute & .178 & .219 \\
$\begin{array}{l}\text { Extreme } \\
\text { Differences }\end{array}$ & Positive & .169 & .177 \\
& Negative & -.178 & -.219 \\
& & & \\
Kolmogorov-Smirnov Z & .794 & .978 \\
Asymp. Sig. (2-tailed) & .553 & .294 \\
\hline
\end{tabular}

Berdasarkan hasil uji normalitas Uji Kolmogorov-Smirnov, tampak bahwa pretest kelas kontrol nilai Sig. $=0,553>0,05$ dan pretest kelas ekperimen nilai Sig. = $0,294>0,05$. Tampak bahwa dari kedua uji tersebut dapat disimpulkan bahwa data Nilai Pretest kelas kontrol dan eksperimen berdistribusi Normal.

Uji Homogenitas Pretest kelas Kontrol dan Kelas Eksperimen

Uji prasyarat lain selain uji normalitas adalah uji homogenitas. Uji Homogenitas juga diperlukan sebagai uji prasyarat analisis statistik terhadap kedua data pretest. Pada uji Homogenitas juga didasarkan pada ketentuan pengujian hipotesis homogenitas yaitu dengan melihat nilai Sig. dan menggunakan taraf signifikansi $(\alpha=5 \%)$, yaitu apabila nilai Sig. $>a$, maka kedua data memiliki varians yang 
homogen, dan sebaliknya jika nilai Sig.< a maka kedua data tidak memiliki varians yang homogen. Uji homogenitas pada penelitian ini dapat dilihat pada Tabel 3.

Tabel 4. Hasil Uji Homogenitas Pretest Kelas Kontrol dan Kelas Eksperimen

\begin{tabular}{rrrr}
\hline $\begin{array}{c}\text { Levene } \\
\text { Statistic }\end{array}$ & df1 & \multicolumn{1}{c}{ df2 } & Sig. \\
\hline .015 & 2 & 14 & .985 \\
\hline
\end{tabular}

Berdasarkan output atau hasil SPSS di atas diperoleh nilai Sig. 0,985 > $(\alpha=$ $0,05)$, dengan demikian dapat disimpulkan bahwa kedua data pretest tersebut memiliki varians yang homogen.

Uji Hipotesis Pretest Kelas Kontrol dan Kelas Eksperimen

Pengolahan data selanjutnya yaitu pengujian hipotesis yang dilakukan setelah uji normalitas dan uji homogenitas. Uji hipotesis ini menggunakan uji $t$ (" $t$ " test), untuk menguji hipotesis nihil (Ho) yang mengatakan bahwa tidak ada pengaruh nilai sebelum dan sesudah perlakuan terhadap hasil belajar kimia peserta didik. Pengujian hipotesis digunakan uji " $\mathrm{t}$ " pada taraf signikan $a=5 \%$ dan derajat kebebasan 19. Adapun cara pengambilan keputusannya adalah jika $t_{\text {hitung }}>t_{\text {tabel }}$ maka Ho ditolak, jika $t_{\text {hitung }}<t_{\text {tabel }}$ maka Ho diterima. Hasil pengujian hipotesis dapat dilihat pada Tabel 5.
Berdasarkan hasil perhitungan di-

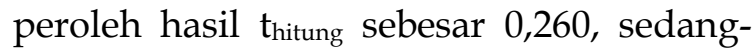
kan $t_{\text {tabel }}$ sebesar 2,093. Pengambilan keputusan bisa juga dilihat dari nilai Sig.(2tailed) dengan nilai $a=5 \%$. Dapat dilihat juga bahwa nilai sig.(2-tailed) $=0,798>a=$ 0,05. Dari penjelasan tersebut dengan membandingkan dua hal maka dapat disimpulkan bahwa Ho diterima yang berarti bahwa untuk pretest kelas kontrol dan eksperimen tidak ada pengaruh nilai sebelum perlakuan terhadap hasil belajar kimia.

Uji Normalitas Posttest Kelas Kontrol dan Kelas Ekperimen

Sama seperti pretest, sebelum dilakukan pengolahan lebih lanjut tentang posttest maka dilakukan uji normalitas terlebih dahulu. Pengambilan keputusan didasarkan dengan ketentuan pengujian hipotesis normalitas dengan melihat nilai Sig. dan menggunakan taraf signifikansi ( $\alpha$ $=5 \%$, yaitu apabila nilai Sig. $>a$, maka data berdistribusi normal, dan sebaliknya jika nilai Sig.< a maka data tidak berdistribusi normal. Data uji normalitas posttest dapat dilihat pada Tabel 6 .

Berdasarkan Tabel 6 dengan menggunakan taraf signifikansi $5 \%$, yaitu uji Kolmogorov-Smirnov, tampak bahwa posttest kelas kontrol nilai Sig. $=0,607>0,05$ dan postest kelas ekperimen nilai Sig. = $0,283>0,05$. Tampak bahwa dari uji tersebut dapat disimpulkan bahwa data Nilai Postest kelas kontrol dan eksperimen berdistribusi normal.

Tabel 5. Hasil Uji “ $t$ ” Pretest Kelas Kontrol dan Kelas Eksperi

\begin{tabular}{|c|c|c|c|c|c|c|c|c|c|}
\hline & & \multicolumn{5}{|c|}{ Paired Differences } & \multirow[b]{2}{*}{ Morn } & \multirow{2}{*}{$\begin{array}{c}\text { Df } \\
\text { Std. } \\
\text { Deviatio } \\
n\end{array}$} & $\begin{array}{l}\text { Sig. (2- } \\
\text { tailed) }\end{array}$ \\
\hline & & Mean & $\begin{array}{c}\text { Std. } \\
\text { Deviation }\end{array}$ & $\begin{array}{l}\text { Std. Error } \\
\text { Mean }\end{array}$ & $\begin{array}{r}95 \% \text { Co } \\
\text { Interv } \\
\text { Diffe }\end{array}$ & $\begin{array}{l}\text { fidence } \\
\text { of the } \\
\text { ence }\end{array}$ & & & $\begin{array}{l}\text { Std. Error } \\
\text { Mean }\end{array}$ \\
\hline & & Lower & Upper & Lower & Upper & Lower & Upper & Lower & Upper \\
\hline Pair 1 & $\begin{array}{l}\text { kls pretes } \\
\text { kontrol - kls } \\
\text { pretes } \\
\text { eksperimen }\end{array}$ & .600 & 10.323 & 2.308 & -4.231 & 5.431 & .260 & 19 & .798 \\
\hline
\end{tabular}


Tabel 6. Hasil Uji Normalitas Posttest Kelas Kontrol dan Kelas Eksperimen

\begin{tabular}{|c|c|c|c|}
\hline & & $\begin{array}{c}\text { kelas } \\
\text { kontrol } \\
\text { postes }\end{array}$ & $\begin{array}{c}\text { kelas } \\
\text { ekspreimen } \\
\text { postes }\end{array}$ \\
\hline $\mathrm{N}$ & & 20 & 20 \\
\hline \multirow[t]{2}{*}{$\begin{array}{l}\text { Normal } \\
\text { Parameters }(a, b)\end{array}$} & Mean & 70.40 & 87.60 \\
\hline & Std. Deviation & 9.029 & 5.491 \\
\hline \multirow[t]{3}{*}{$\begin{array}{l}\text { Most Extreme } \\
\text { Differences }\end{array}$} & Absolute & .170 & .221 \\
\hline & Positive & .161 & .221 \\
\hline & Negative & -.170 & -.129 \\
\hline \multicolumn{2}{|c|}{ Kolmogorov-Smirnov Z } & .762 & .988 \\
\hline \multicolumn{2}{|c|}{ Asymp. Sig. (2-tailed) } & .607 & .283 \\
\hline
\end{tabular}

Uji Homogenitas Kelas Kontrol dan Kelas Ekperimen

Setelah data posttest dinyatakan berdistribusi normal selanjutnya dicari nilai homogenitasnya. Data hasil uji homogenitas dapat dilihat pada Tabel 7.

Tabel 7. Hasil Uji Homogenitas Posttest Kelas Kontrol dan Kelas Eksperimen

\begin{tabular}{rrrr}
\hline Levene Statistic & df1 & df2 & Sig. \\
\hline 1.909 & 4 & 12 & .174 \\
\hline
\end{tabular}

Berdasarkan output atau hasil SPSS di atas diperoleh nilai Sig. 0,174 $>(\alpha=$ $0,05)$, dengan demikian dapat disimpulkan bahwa kedua data posttest tersebut memiliki varians yang homogen.

Uji Hipotesis Posttest Kelas Kontrol dan Kelas Eksperimen

Uji hipotesis menggunakan uji " $\mathrm{t}$ " pada taraf signikan $a=5 \%$ dan derajat kebebasan 19. Adapun cara pengambilan keputusannya adalah: jika $t_{\text {hitung }}>t_{\text {tabel }}$ maka Ho ditolak, jika $t_{\text {hitung }}<t_{\text {tabel }}$ maka Ho diterima. Data hasil uji hipotesis posttest dapat dilihat pada Tabel 8 .

Berdasarkan hasil perhitungan diperoleh hasil $t_{\text {hitung }}$ sebesar 7,844 , sedangkan $t_{\text {tabel }}$ sebesar 2,093. Pengambilan keputusan bisa juga dilihat dari nilai Sig.(2tailed) dengan nilai $\alpha=5 \%$. Dapat dilihat juga bahwa nilai sig.(2-tailed) $=0,000<\alpha=$ 0,05 . Dari penjelasan tersebut dengan membandingkan dua hal maka dapat disimpulkan bahwa Ho ditolak yang berarti bahwa untuk potstest kelas kontrol dan kelas eksperimen ada pengaruh nilai sebelum dan sesudah perlakuan terhadap hasil belajar kimia, nilai negatif (-) pada $t_{\text {hitung }}$ menunjukkan nilai rata-rata kelas kontrol lebih rendah dari nilai rata-rata kelas ekperimen.

Berdasarkan data hasil posttest, diperoleh data hasil belajar peserta didik kelas eksperimen $>$ kelas kontrol. Artinya dapat disimpulkan bahwa ada perbedaan hasil belajar peserta didik antara yang mengikuti proses pembelajaran dengan menggunakan metode pembelajaran inquiry dengan yang mengikuti proses pembelajaran dengan menggunakan metode pembelajaran demonsrasi dimana peserta didik yang mengikuti proses pembelajaran dengan mengikuti metode pembelajaran inquiry lebih besar hasil belajarnya dari pada peserta didik yang mengikuti proses pembelajaran dengan metode pembelajaran demonstrasi.

Tabel 8. Hasil Uji " $\mathrm{t}$ ” Postest Kelas Kontrol dan Kelas Eksperimen

\begin{tabular}{lccccccccc}
\hline & \multicolumn{4}{c}{ Paired Differences } & t & Df & $\begin{array}{c}\text { Sig. (2- } \\
\text { tailed) }\end{array}$ \\
\hline & Mean & Mean & Deviation & Std. Error Mean & Mean & $\begin{array}{c}\text { Std. } \\
\text { Deviation }\end{array}$ & Std. Error \\
Paired kls posttes
\end{tabular}




\section{Hasil Data N-Gain}

Hasil data n-gain pada kelas eksperimen termasuk dalam kategori tinggi dengan nilai rata-rata 0,77 . Peserta didik yang mempunyai nilai kategori tinggi sebanyak 18 peserta didik dan sedang sebanyak 2 peserta didik. Sementara untuk kelas kontrol termasuk dalam kategori sedang dengan nilai rata-rata 0,44 . Semua peserta didik mempunyai nilai kategori sedang yaitu 20 peserta didik. Adapun kategorisasi n-gain kelas kontrol dan kelas eksperimen disajikan dalam Tabel 9.

Tabel 9. Kategorisasi N-gain kelas kontrol dan eksperimen

\begin{tabular}{ccc}
\hline Kategorisasi & $\begin{array}{c}\text { Frekuensi } \\
\text { Kelas Kontrol }\end{array}$ & $\begin{array}{c}\text { Frekuensi } \\
\text { Kelas } \\
\text { Eksperimen }\end{array}$ \\
\hline Tinggi & - & 18 \\
Sedang & 20 & 2 \\
Rendah & - & - \\
Jumlah & 20 & 20 \\
\hline
\end{tabular}

Pembahasan

Penelitian yang dilakukan dapat membuktikan adanya perbedaan yang signifikan antara keaktifan belajar dan hasil belajar peserta didik dengan menggunakan metode pembelajaran inquiry pada kelas eksperimen dan metode pembelajaran demonstrasi pada kelas kontrol. Hasil penelitian menunjukan penggunaan metode pembelajaran inqury dapat menjadikan peserta didik lebih aktif dan lebih tinggi hasil belajarnya dibandingkan dengan metode pembelajaran demonstrasi. Hal ini dapat dilihat dari hasil observasi dan angket tentang keaktifan serta hasil tes belajar peserta didik.

Berdasarkan hasil observasi diperoleh data kelas eksperimen $>$ kelas kontrol artinya ada perbedaan keaktifan belajar peserta didik antara peserta didik yang mengikuti proses pembelajaran dengan menggunakan metode pembelajaran inquiry dengan keaktifan belajar peserta didik yang mengikuti proses pembelajaran menggunakan metode pembelajaran de- monstrasi. Hal ini ditunjukan pada data hasil observasi pada setiap aspek-aspek keaktifan yang diamati. Pada jenis visual activities, kelas eksperimen yang menggunakan metode pembelajaran inquiry ratarata nilai observasi lebih besar $19,65 \%$ dari pada kelas kontrol yang menggunakan metode pembelajaran demonstrasi. Sementara pada kelas eksperimen jenis oral activities lebih besar 30,48\%, listening activities lebih besar $48 \%$, writing activities lebih besar $15,25 \%$, motor activities lebih besar 15,66\% dan mental activities lebih besar 22,20\% dibandingakan dengan kelas kontrol.

Data hasil observasi juga didukung dari data angket keaktifan peserta didik. Pada jenis visual activities lebih besar 15\%, oral activities lebih besar $28,60 \%$, listening activities lebih besar 51,40\%, writing activities lebih besar 17,6\%, motor activities lebih besar $16 \%$, dan mental activities lebih besar $15,8 \%$.

Berdasarkan tes hasil belajar peserta didik diperoleh dari hasil pretest, posttest dan normal gain kelas eksperimen yang menggunakan metode pembelajaran inquiry dan kelas kontrol yang menggunakan metode pembelajaran demonstrasi. Pengujian hipotesis sebelumnya, menyatakan bahwa ada perbedaan metode pembelajaran inquiry dengan metode pembelajaran demonstrasi terhadap hasil belajar peserta didik. Setelah melakukan uji normalitas dan uji homogenitas, diketahui bahwa kedua kelas berdistribusi normal dan homogen, maka dari itu pengujian hipotesis menggunakan " $\mathrm{t}$ "test. Uji " $\mathrm{t}$ "yang dilakukan bertujuan untuk mengetahui perbedaan metode pembelajaran inquiry dengan metode pembelajaran demonstrasi terhadap hasil belajar peserta didik. Uji " $\mathrm{t}$ " dilakukan dengan membandingkan posttest pada masing-masing kelas.

Pengujian posttest yang telah diberikan perlakuan berbeda antara kelas eksperimen dan kelas kontrol, dimana kelas eksperimen menggunakan metode pembelajaran inquiry dan kelas kontrol menggunakan metode pembelajaran demonstrasi. Melalui uji " $t$ " untuk kelas eksperimen dan 
kelas kontrol diperoleh hasil $t_{\text {hitung }}=7,844$ dengan derajat kebebasan 19, maka diperoleh $t_{\text {tabel }}$ pada taraf signifikasnsi 0,05 sebesar 2,093. Data tersebut menunjukan $t_{\text {hitung }} 7,844>t_{\text {tabel }} 2,093$, artinya ada perbedaan hasil belajar antara peserta didik yang mengikuti proses pembelajaran dengan menggunakan metode pembelajaran inquiry dengan peserta didik yang mengikuti proses pembelajaran dengan menggunakan metode pembelajaran demonstrasi.

Berdasarkan perolehan nilai n-gain, kelas eksperimen memiliki rata-rata 0,77 dengan kategori tinggi sebanyak 18 peserta didik dan sedang sebanyak 2 peserta didik. Sedangkan kelas kontrol memiliki rata-rata 0,44 dengan kategori sedang sebanyak 20 peserta didik. Data tersebut menunjukan bahwa peserta didik kelas eksperimen mempunyai hasil rata-rata dan kategori ngain lebih tinggi dibandingkan dengan kelas kontrol.

Keberhasilan metode pembelajaran inquiry untuk meningkatkan keaktifan dan hasil belajar peserta didik tidak terlepas dari beberapa hal yang terkait dengan proses pembelajaran dan kemampuan peserta didik. Proses pembelajaran diawali dengan membentuk kelompok kecil yang terdiri dari lima peserta didik yang dipilih secara heterogen, kemudian pendidik menyampaikan apersepsi dan penjelasan sedikit tentang materi hidrokarbon yang akan dipelajari, kemudian pendidik membagi LKPD pada masing-masing kelompok, mengarahkan peserta didik untuk berdiskusi mengenai masalah yang terdapat di dalam LKPD, kemudian peserta didik melakukan percobaan untuk membuktikan hipotesis hasil diskusi dan menarik kesimpulan dari hasil percobaan yang sudah peserta didik lakukan, kemudian pendidik mengarahkan peserta didik melakukan presentasi tentang hasil percobaan yang mereka lakukan dan mengumpulkan hasil laporan kepada pendidik. Dalam proses pembelajaran tersebut pendidik menilai keaktifan peserta didik dan menilai hasil belajar peserta didik setelah mengikuti proses pembelajaran. Proses tersebut sesuai de- ngan langkah-langkah metode pembelajaran inquiry menurut Roestiyah (2012, p. 75) yang menyatakan bahwa pelaksanaan metode pembelajaran inquiry adalah pendidik membagi tugas meneliti suatu masalah ke kelas, peserta didik dibagi menjadi beberapa kelompok, dan masing-masing kelompok mendapatkan tugas untuk dikerjakan. Kemudian mereka mempelajari, meneliti atau membahas tugasnya dalam kelompok. Setelah hasil kerja mereka dalam kelompok didiskusikan, kemudian dibuat laporan yang tersusun dengan baik.

Keaktifan peserta didik pada tiap indikator menunjukan bahwa persentase terbesar keaktifan peserta didik adalah pada listening activities (peserta didik mendengarkan penyampaian hasil diskusi masing-masing kelompok) yaitu sebesar $94 \%$ yang menunjukan keaktifan itu termasuk kelompok keaktifan sangat baik menurut Sugiyono. Sedangkan presentase keaktifan terkecil adalah mental activities (menanggapi pertanyaan pendidik saat apersepsi, menyelesaikan masalah dengan mencari di berbagai sumber belajar, bertanya kepada teman apabila belum paham dalam menyelesaikan masalah yang dihadapi, bertanya kepada pendidik jika kesulitan dalam melakukan percobaan dan menanggapi pertanyaan saat penyampain hasil diskusi) yaitu sebesar $47 \%$ yang termasuk dalam kategori sedang.

Kurangnya keaktifan yang baik dari peserta didik disebabkan oleh beberapa hal, antara lain dalam dsikusi kelas jumlah peserta didik yang bertanya maupun yang menanggapi pertanyaan masih sedikit dan terbatas hanya pada peserta didik yang berkemampuan tinggi dan memiliki keberanian. Keinginan peserta didik untuk bertanya kepada pendidik saat percobaan juga kecil, walaupun ada bebarapa peserta didik yang bertanya kepada pendidik, Namun mereka adalah peserta didik yang tergolong kelompok atas dalam tingkat keberhasilan pembelajaran.

Peran pendidik sebagai fasilitator yaitu memberikan arahan atau jawaban yang dapat merangsang peserta didik un- 
tuk menyimpulkan sendiri atas pertanyaan yang mereka ajukan. Seperti saat seoarang peserta didik bertanya "Pak, kenapa tepung beras dan susu bubuk berubah warna menjadi hitam?". Pendidik memberikan jawaban dengan menanyakan kepada peserta didik tentang apa itu reaksi oksidasi. Setelah peserta didik menyampaikan pengetahuannya tentang reaksi oksidasi, maka peserta didik dapat menjawab pertanyaannya sendiri.

Proses pembelajaran dengan metode inquiry yang dilaksanakan dalam pembelajaran adalah diskusi dalam merancang percobaan untuk menguji keberadaan karbon dan hidrogen, menentukan posisi atom karbon dan menentukan bentuk rantai karbon jenuh dan tidak jenuh serta siklik dan alisiklik, mengkonstruksi deret homolog dan penamaan alkana, alkena dan alkuna, menentukan isomer alkana, alkena dan alkuna dan menuliskan reaksi sederhana pada senyawa hidrokarbon. Dalam pelaksanaannya masih banyak peserta didik yang bertanya-tanya bagaimana merancang percobaan untuk membuktikan hipotesis hal ini dikarenakan faktor belum terbiasanya peserta didik dalam mengikuti metode pembelajaran inquiry yang memungkinkan peserta didik untuk merancang percobaan sesuai petunjuk yang ada pada LKPD.

Pada saat melakukan percobaan ada banyak hal yang peserta didik temukan dan itu merupakan hal yang baru bagi mereka. Untuk mengetahui hal-hal baru yang belum mereka pahami, mereka mengajukan pertanyaan kepada pendidik maupun teman mereka sendiri. Pada proses pembelajaran, peserta didik mencari literatur, melakukan percobaan, melakukan diskusi dan bertanya itulah muncul keaktifan dan keseriusan peserta didik dalam memecahkan masalah. Berdasarkan pengetahuan yang diperoleh peneliti dari pendidik sebelumnya bahwa biasanya peserta didik jarang mencari informasi selain dari yang diberikan pendidik, berpendapat dan bertanya namun setelah mengikuti pembelajaran dengan metode pembelajaran inqu- iry peserta didik menjadi lebih sering mencari informasi tentang apa yang mereka pelajari, berpendapat pada saat berdiskusi dan bertanya kepada pendidik maupun teman tentang hal-hal yang belum peserta didik ketahui.

Keberhasilan penerapan metode pembelajaran inquiry tidak terlepas bahwa terdapat ketertarikan peserta didik terhadap proses pembelajaran. Peserta didik merasa dengan metode pembelajaran inquiry mereka menjadi lebih memahami materi pembelajaran karena mereka terlibat langsung dalam setiap proses pembelajaran yang mereka alami. Meskipun dalam proses pembelajarannya masih ada beberapa peserta didik yang tampak belum paham terhadap proses pembelajaran inquiry yang diterapkan, pada akhirnya peserta didik mulai membiasakan diri dengan proses pembelajaran dimana mereka sendiri yang lebih banyak berperan dalam proses pembelajaran. Pemahaman yang didapatkan peserta didik setelah mengikuti proses pembelajaran dengan menggunakan metode pembelajaran inquiry bukan sematamata berasal dari pemikiran pendidik yang dituangkan langsung sepenuhnya ke dalam pemikiran peserta didik, namun pemahaman tersebut diperoleh dari hasil pengalaman-pengalaman mereka melalui diskusi dan percobaan yang telah dilakukan. Peserta didik membangun sendiri dasar dari pengetahuan yang telah didapatkannya pada saat proses pembelajarannya berlangsung. Dari pengalaman dan keaktifan peserta didik selama mengikuti proses pembelajaran dengan menggunakan metode pembelajaran inquiry hasil belajar peserta didik juga meningkat. Hal ini sesuai dengan kerucut pengalaman belajar Peter Sheal dalam Fajar (2004, p. 88) yang menyatakan bahwa pengalaman belajar yang paling baik adalah dengan mengatakan dan melakukan dimana dengan menggunakan metode pembelajaran inquiry peserta didik aktif melakukan berbagai kegiatan dalam proses pembelajaran sehingga berbanding lurus dengan hasil belajar peserta didik. 


\section{Simpulan dan Saran}

Simpulan

Berdasarkan hasil penelitian dan analisis data, maka diperoleh kesimpulan (1) Adanya perbedaan keaktifan belajar yang signifikan antara penerapan metode pembelajaran inqury dibandingkan dengan metode pembelajaran demonstrasi terhadap keaktifan belajar peserta didik. Artinya keaktifan belajar peserta didik yang mengikuti proses pembelajaran dengan menggunakan metode pembelajaran inquiry lebih aktif dari pada peserta didik yang mengikuti proses pembelajaran menggunakan metode pembelajaran demonstrasi. (2) Adanya perbedaan hasil belajar yang signifikan antara penerapan metode pembelajaran inqury dibandingkan dengan metode pembelajaran demonstrasi terhadap hasil belajar peserta didik. Artinya hasil belajar peserta didik yang mengikuti proses pembelajaran dengan menggunakan metode pembelajaran inquiry lebih tinggi dari pada peserta didik yang mengikuti proses pembelajaran menggunakan metode pembelajaran demonstrasi

Saran

Berdasarkan temuan-temuan selama penelitian, peneliti mengajukan beberapa saran sebagai sarana perbaikan dimasa mendatang yaitu (1) penerapan metode inquiry dapat digunakan sebagai salah satu metode pembelajaran alternatif dalam upaya meningkatkan keaktifan dan hasil belajar peserta didik. (2) pelaksanaan pembelajaran dengan menggunakan metode pembelajaran inquiry harus memperhatikan waktu, karena penerapan metode pembelajaran inquiry membutuhkan waktu yang lama. (3) sebelum melakukan pembelajaran dengan menggunakan metode pembelajaran inquiry sebaiknya terlebih dahulu dilakukan persiapan alat dan bahan yang dibutuhkan. (4) pendidik dalam mengajukan pertanyaan-pertanyaan sebaiknya mengajukan pertanyaan yang dapat merangsang peserta didik untuk berfikir dan membuat peserta didik aktif dalam mencari jawaban atas pertanyaan yang diajukan. (5) sebelum melaksanakan pembelajaran pendidik sebaiknya mengkondisikan peserta didik untuk siap dalam mengikuti proses pembelajaran. (6) pendidik harus kreatif dalam memanfaatkan sarana dan prasarana untuk menunjang proses pembelajaran dengan menggunakan metode pembelajaran inquiry.

\section{Daftar Pustaka}

Dimyati dan Mudjiono. (2009). Belajar dan Pembelajaran.Jakarta:Rineka Cipta.

Fajar, Arnie. (2004). Portofolio dalam pembelajaran IPS. Bandung: Rosdakarya

Jeffrey H.D, Cornelius-White \& Adam P.H. (2009). Learned-Centered Intruction : Building Relationships for Student Success. California, Sage Publications

Mulyasa, E. (2008). Kurikulum Tingkat Satuan Pendidikan; Sebuah Panduan Praktis. Bandung: PT Remaja Rosdakarya.

Roestiyah. (2012). Strategi Belajar Mengajar.Jakarta: Rineka Cipta

Sardiman. (2014). Interaksi dan Motivasi Belajar Mengajar. Jakarta: Raja Grafindo Persada.

Sugiyono.(2012). Metode penelitian pendidikan (pendekatan kuantitatif, kualitatif dan $R \mathcal{E} D$. Bandung: Alfabeta

Sudjono, Anas.(20012). Pengantar Statistik Pendidikan. Jakarta: Raja Grafindo

Suyono dan Hariyanto. (2012). Belajar dan Pembelajaran: Teori dan Konsep Dasar. Bandung: Rosdakarya

Trianto. (2010). Mendesain Model Pembelajaran Inovatif-Progresif: Konsep, Landasan dan Implementasinya pada Kurikulum Tingkat Satuan Pendidikan (KTSP). Jakarta: Kencana Prenada Media Group. 